Z Badań nad Książką i Księgozbiorami Historycznymi 2019. T. specjalny: Dla Niepodległej The Studies into the History of the Book and Book Collections 2019. Special issue: For an Independent Poland

\title{
Characteristics of the Polish film press market in the academic literature: from the first film journals until 1939
}

\begin{abstract}
The Polish film press in the first half of the $20^{\text {th }}$ century (1913-1939) tried to find its place in the Polish publishing market. Inspired by film thought and still developing Polish and global cinematography, the Polish press wanted to uphold true art. However, the times of censorship, interference of state authorities, fragile publishing politics, and omnipresent commercialism have all strongly influenced the history of the Polish film press. The article mainly presents the history and characteristics of film journals, dividing them into those loyal to the art of cinematography, as well as those that have been commercially influenced by film in general. It describes their profiles, forms, language, as well as editorial policy of individual editorial offices used to get valuable readers.
\end{abstract}

Key words: film press - movie - periodicals - press market - censorship.

„Z Badań nad Książką i Księgozbiorami Historycznymi” - Udział zagranicznych recenzentów w ocenie publikacji; Stworzenie anglojęzycznej wersji wydawniczej publikacji; Digitalizacja tomów archiwalnych rocznika w celu zapewnienia otwartego dostępu do nich przez Internet oraz wdrożenie i utrzymanie cyfrowej platformy redakcyjnej - zadanie finansowane w ramach umowy $\mathrm{nr}$ 653/P-DUN/2019 ze środków Ministra Nauki i Szkolnictwa Wyższego przeznaczonych na działalność upowszechniającą naukę. 
The film press has hardly been studied or described in the academic literature. The author analyses a part of film press history - its development - considering also its inherent relation to the beginnings of the Polish cinematography and film thought, born at the end of the $19^{\text {th }}$ century. The text is based on a literature review, including research publications concerning film press in the defined period.

The end of the $19^{\text {th }}$ century in Poland is the beginning of the artistic period of Young Poland, unfavourable and not understanding the development of national cinematography. First film projections, which took place in France and England in 1895, and in 1896 in Warsaw, on the occasion of the moving pictures presentation, have not been perceived as a unique art discovery. The cinema was seen as primitive pleaser for the poorest class at the turnover of the $19^{\text {th }}$ and $20^{\text {th }}$ centuries, as it was one of the cheapest forms of entertainment of that time. Therefore also a cinema, from its beginnings, was discussed and analyzed in public and science critique. One of the first Polish film publications is Nowe źródto historii (A new source of history) work by Bolesław Matuszewski of 1898, published originally in French in Paris. The author presents the archiving function of a film, evident witness of history. B. Matuszewski was a protagonist of the film press and a pioneer of a science film. As one of the first promoters of cinematography, he initiated the establishment of a film-concerned journal. He aimed at discussing there problems of movement transmission, a technique of projection of animated photography, and many others. The "Bulletin of Photography and Cinematography" by B. Matuszewski was published after two years, in 1900 in Paris. More and more pioneer publications or speeches related to film thought emerged in the Young Poland period. At the beginning of the $20^{\text {th }}$ century, the cinematographic production was hardly active in the Polish territories (only two fiction films were made). Moreover, no cinematographic institute existed, to gather a film community. However, this was not a barrier to developing film thought ${ }^{2}$. Many Polish critics analyzed and expressed their opinions on cinematography development in both Polish and foreign journals. A controversy arose in the meantime, concerning theatre and cinema, noticed by Ignacy Chrzanowski (among others), who wrote: "theatre becomes now an entertainment place instead of the temple of art"3. It is worth nothing that the journalistic polemics on theatre and film concerned social rather than aesthetic values of the film. Zdzisław Dębicki, Warsaw publicist, defended cinematography; in his article in "Tygodnik Ilustrowany" he noticed that theatres for masses had still been lacking in Poland, which would be not

\footnotetext{
W. Jewsiewicki, Polska Kinematografia w okresie filmu niemego, Łódź 1966, pp. 13-14.

J. Bocheńska, Polska myśl filmowa do roku 1939, Warszawa 1974, pp. 24-28.

I. Chrzanowski, W obronie teatru, "Scena i Sztuka" 1909, supplement no 1 to no 37, p. 3.
} 
a rarity only for the upper class. Dębicki considered that a crowd that did not understand the contents of words of great thinkers and poets would understand the one coming from moving pictures ${ }^{4}$.

While literary critics were eagerly disputing advantages and place of cinema in the popular culture, theoreticians related to film practice focused mostly on artistic features of the films, ignoring their trivial plots.

Leo Belmont, a professional lawyer, and an amateur writer author of the article "Hołd kinematografowi" 5 , should be distinguished from among this group of theoreticians. The article was published in the social and literary weekly "Wolne Słowo" (Free Word), edited in total by Belmont. In his text, the author criticized attitude towards this invention, which was received contemptuously in a film community. This contempt resulted from a bad attitude towards this new medium. According to Belmont, a cinema in the years 1895-1910 was described as a "trashy" one, however, for either society or film researchers, it was a historical archive, which enabled learning about the past through its moving images, and directed a viewer towards a present. It was a tool of exploring the world, and entertainment for the masses, answering the needs of society ${ }^{6}$. The statement that the film is an art form was claimed already at the beginning of the film. Karol Irzykowski, Polish literary and film critic, referred to it in his article "Śmierć kinematografu", published in "Świat" (The World) weekly in $1913^{7}$. To the intriguing question "Is cinema art?" Irzykowski answered: "it is an ore containing precious and valuable material for the art" cinema as a spectacle, not aiming at its ennoblement to the rank of the art at all costs. Irzykowski joined cinema also with poetry, writing: "A film is a tool more flexible than theatre, maybe even fundamentally different, namely equivalent of thoughts, such volatile and lively as poetry" . Irzykowski, comparing cinema to poetry, and being a poet himself, included it in the most precious values, in his opinion ${ }^{10}$.

Interest in film increased in the first decade of the $20^{\text {th }}$ century, which resulted in an increased number of Warsaw cinemas. Thanks to innovations and technologies, fiction films have begun to be made in Poland, attracting the public to the screens with its form and content. Increasing demand for such entertainment motivated entrepreneurs to open their own, private cinemas. They were

\footnotetext{
4 Z. Dębicki, Czy kinematograf profanuje dzieło sztuki?, "Tygodnik Ilustrowany" 1911, no 51, p. 1025 .

L. Belmont, Hołd kinematografowi, "Wolne Słowo" 1909, no 44-45, p. 14.

Ibidem, p. 15 .

M. Hendrykowska, Kronika kinematografii polskiej, Poznań 1999, pp. 19-20.

K. Irzykowski, Śmierć kinematografu, "Świat” 1913, no 21, p. 2.

Ibidem, p. 3.

10 Z. Dębicki, Czy kinematograf profanuje dzieło sztuki?..., p. 1025.
} 
organized in rented fire stations, formertheatre halls, or in bigger shops. 30 cinemas were active in Warsaw in 1911. "Apollo" was the first and the biggest one, with 750 seats, at Bielańska street. It was established in 1913 by Mojżesz Lejman, a tailor, and a trader. The number of cinemas increasing year by year contributed to the establishment of the film rental office. One of the first, named "Siła", was opened in 1910 by Mojżesz Towbin, the owner of "Oaza" cinema. Aleksander Hertz was a founder of "Sfinks" agency, creator of the film industry in Poland. Six film rental offices were active in Warsaw until the end of 1911. Domestic offices cooperated and maintained relations with film companies in (among others) Moscow and Petersburg. Thanks to these connections they had an opportunity to provide Polish cinemas with the latest foreign film productions ${ }^{11}$.

The years 1911-1913 cover the period of intensified discussion on the future of the cinema, its influence and significance in the world. These discussions had been developed within film-related publications of that time. Pioneer press titles concerning cinematography were published in Germany and Vienna. Domestic titles got inspired by them. According to Wiktor Jewsiewicki, film historian, aversion to cinema, especially noticeable in artistic and literary groups, intensified in 1913. It resulted in numerous publications concerning multiple prejudices towards cinema. Therefore it is no coincidence that the first Polish film journal "Scena i Ekran" (Scene \& Screen) was published in the same year. It was printed in Lwów, under the auspices of "Leopolia" film company of Adam and Ludwik Krogulski brothers ${ }^{12}$. The editorial team aimed at raising the cinema's rank in the society, equating it with the theatre, as one of the arts. The main driving force of these activities was the developing French trend of Film d'Art, which brought the classics of literature and theatre to cinema. Articles of Polish scholars, writers, film theoreticians were published in "Scena i Ekran" volumes, like Adam Zagórski, who published in the first volume the text comparing cinema's influence to that of a book, therefore comparing the cinematograph phenomenon to the print one ${ }^{13}$. Ludwik Skoczylas, literary and theatre critic, and education activist, also expressed his opinion. In the text "Kinoteatr - Nowy wróg młodzieży" (Cinema theatre - a new enemy of the youth) he wrote that he was anxiously observing the influence of cinema, as its impact is enormous, mostly with a negative effect. Skoczylas run a study on the youth from lower secondary schools in Lwów, looking for the reasons of cinema increasing popularity, and its influence on young people ${ }^{14}$. In his

11 W. Jewsiewicki, Polska kinematografia..., pp. 35-40.

12 M. Halberda, Polska prasa filmowa do 1929 roku, "Kwartalnik Historii Prasy Polskiej" 1989, no 28/4, p. 24.

13 A. Zagórski, Przyszłość kinematografu, "Scena i Ekran" 1913, no 1, p. 10.

14 J. Skoczylas, Kinoteatr. Nowy wróg młodzieży, "Wychowanie i Nauczanie” 1918, no 1, pp. 15-16. 
article, among the reasons for film demand, he listed common accessibility, as well as the suggestive power of film impressions ${ }^{15}$. As a negative aspect, he perceived that cinema directs the youth's imagination in the wrong direction. He underlined that education needed basic reforms in regard to changing technology. He clearly and distinctly diagnosed that the youth, apart from entertainment, searched for close relation to life in the cinema ${ }^{16}$.

A few unsuccessful attempts of publishing film journals had been noted before World War I, as in the case of "Kino-Teatr i Sport" (Cinema-Theatre \& Sport), published in $1914^{17}$. It was the first pre-war film journal of popular character published in Warsaw. It offered articles concerning cinema, theatre, and sport. Interestingly, its Chief editor was Aleksander Drac - the first Polish sports journalist, who previously edited "Gazeta Sportowa" (Sport Gazette) and "Sport". The main aim of "Kino-Teatr i Sport" was shaping taste in film. It published reviews and information on film new releases, and besides that materials, which had been an impulse for future discussions on the development of the Polish cinematography. Aleksander Hertz, a filmmaker, belong to those who expressed here their opinions on the cinema functions and role. Apart from film questions, repertoire of Warsaw theatres was published here, sport news, as well as portraits of Polish theatre actors. Undoubtedly, "Kino-Teatr i Sport" was a pioneering journal, opening the Warsaw press market for film promotion $^{18}$.

The Polish press market was under constant pressure of the occupant during World War I, therefore it changed its original functions. A significant reduction of titles' numbers took place in all three partitions and in the Kingdom of Poland. The development of professional and scientific press was blocked, and publication of other journal types limited. Besides, distribution was limited, paper and printing equipment rationed, due to war deficit. The information flow was strictly supervised. Often calls to military service caused a noticeable lack of professionals. Destroying warfare also influenced the press market. The invaders-friendly daily press was less censored. Its main goal was to inform the society about current warfare that the nation lived in that period. The time of World War I marked the shape of the Polish press. News and political press were mostly active in these hard times, other journals revived only at the end of the war ${ }^{19}$.

Status and rules of functioning of the film press in the $2^{\text {nd }}$ People's Republic of Poland were under general press law. Legal rules of press activity were

\footnotetext{
15 Ibidem, p. 38.

16 Ibidem, pp. 13-14.

17 B. Gierszewska, Czasopiśmiennictwo filmowe w Polsce do 1939 roku, Kielce 1995, p. 92.

18 Ibidem, pp. 89-90.

19 J. Łojek, J. Myśliński, W. Władyka, Dzieje prasy polskiej, Warszawa 1988, pp. 89-92.
} 
partially regulated by the Polish Constitution of March 21, 1921, while legal rules concerning (among others) establishment of journals and press crimes until 1918 were based on the acts on press and penal codes of invader states. It resulted in law abuse and circumvention for reaching goals. The rules regulating press functioning in Poland in that time, despite inconsistency, were liberal, warranted freedom of press and prohibition of censorship. In consequence, courts and administration had no reason to intervene in the journals' content ${ }^{20}$. Situation at the Polish press market changed after the May Coup when in 1926 Józef Piłsudski took the prime minister position and the Regulation on penalties for the dissemination of false news, and on penalties for insulting the authorities and their representatives was accepted. This document limited freedom of speech and press under a penalty of a fine for those who propagate false news. The regulation moved both journalists and lawyers communities, who criticized this document for its pervasive vagueness and stringency ${ }^{21}$. Repeal of these laws by the authorities resulted in new regulations of May 10, 1927, on the press law and changes in selected statements concerning the dissemination of false information and on insults ${ }^{22}$.

On November 21, 1938 Dekret o prawie prasowym (the Decree on press law) was passed. It assumed that the common good is a limit of press freedom. Therefore changes in binding law were introduced. Among others, financial penalties were tightened for press violations. By virtue of this document, the authority was entitled to impose and execute penalties for a crime, among others: to discipline publishers, suspend journals for a limited time, or to deprive a right to a function of editor ${ }^{23}$. The Decree on press law equipped the State with new tools, enhancing press control to protect the State's interests and the public good ${ }^{24}$.

Development of the film press in the interwar period, i.e. its territorial deployment and edition volume, were mostly depended on the public interest in cinema, as well as the cinematography condition in a given region. Therefore the number of film companies, film rental offices, and organizations gathering film professionals influenced significantly existence of film journals. The structure of society, as well as the number of cinemas and sold tickets, were important indicators deciding about numbers and types of journals. The recipients of the film press were mostly industry members, creators, cinema

20 B. Gierszewska, Czasopiśmiennictwo filmowe..., pp. 39-40.

21 R. Habielski, Ewolucja Prawa Prasowego w Drugiej Rzeczypospolitej. Zakres i recepcja, "Studia Medioznawcze" 2013, no 4 (55), p. 83.

22 Ibidem, pp. 86

23 J. Sobczak, Dzieje prawa prasowego na ziemiach polskich, Poznań 2009, p. 92.

24 R. Habielski, Ewolucja Prawa Prasowego w Drugiej Rzeczypospolitej..., p. 89. 
researchers or representatives of the cinematographic industry. It was to be available for the largest possible audience, therefore its prices could not be excessive. The copy price often did not return edition costs, with the exception of such journals as "Kino" (Cinema) or "Przegląd Filmowy, Teatralny, Radiowy" (Film, Theatre, Broadcasting Review), published in Lwów, which were profitable for the publishers. By definition, cheap and available film press were first of all to catch the viewers' attention with a new film repertoire. Photos of movie stars or shoots, as well as rumors and news from the cinema world, were to encourage to buy journals. Many editorials lived for advertising. Unable to count enough on revenue of journal distribution, they saved themselves with selling space for advertisements or announcements. It was the result of the relation between film press and Polish film production, as well as foreign film rental offices. Film journals filled with ads and promotion materials resulted in unofficial division into publications important for the development of the Polish cinematographic culture, and a significant majority of poor titles of low meritorious and publishing levels ${ }^{25}$.

Publishing journals in the $2^{\text {nd }}$ People's Republic of Poland was linked with numerous social, economic and political difficulties. After regaining independence by Poland in 1918, an apparent revival of the press market was observed. Despite war losses and damages in the publishing industry and lack of paper, the Polish press was enriched with many new titles. It had been shaped by political parties and industry concerns, as well as competition and profit right in the interwar period, as publishing journals were a branch of the capitalist economy.

Many film journals emerged in the Polish press market in the years 1919-1923, among others: "Ekran" (The Screen) biweekly of 1919, edited by Franciszek Pik-Mirandola, and published by Tadeusz Bukowiecki, the owner of the Kraków cinema "Uciecha". "Ekran" had a large group of valuable collaborators, to name a known sociologist Jan Bystroń, Karol Irzykowski - theoretician of cinematography, L. Skoczylas - literary critic, and Henryk Uziembło, a painter and graphic designer. This was the first artistic periodical in independent Poland. "Ekran" enlarged the group of its followers thanks to J. Bystroń text Socjologia kina ${ }^{26}$ (Sociology of cinema). The article concerned film thought from the perspective of a cinema either as an artistic creation or an invention to be used in education. It triggered many discussions and was often cited in post-war literature concerning the history of film thought ${ }^{27}$. The editors moved their headquarters to Warsaw in 1919. Due to tempting

\footnotetext{
25 B. Gierszewska, Czasopiśmiennictwo filmowe..., pp. 42-44

26 J. Bystroń, Socjologia kina, "Ekran” 1919, no 11, p. 2.

27 B. Gierszewska, Czasopiśmiennictwo filmowe..., p. 71.
} 
proposals from the representatives of the film industry, "Ekran" became a part of the cinematographic industry ${ }^{28}$. Mieczysław Majcher took over the edition after F. Pik-Mirandola, while its publisher became "Reklama Polska" JointStock Company. "Ekran" moved from an art to an industry journal, which caused changes in its profile, structure, and decrease of an artistic level. Fullpage advertisements of film companies and extensive film characteristics were published in the journal, aimed at enticing the viewers to go to a cinema. 30 issues of "Ekran" were published in the years 1919-1920. Similar fate was later shared by many other Polish film journals, as relevantly commented by Witold Witczak:

duże ambicje niektórych pism, np. "Ekranu”, usiłujących obiektywniej przedstawić stan rodzimej kinematografii, kończyły się szybko. Byt czasopism zależny był od ogłoszeń biur wynajmu, które dyktowały pośrednio poziom i treść publicystyki oraz charakter recenzji ${ }^{29}$. [great ambitions of a few journals, e.g. "Ekran", attempting to present objectively a state of domestic cinematography, were soon finished. Journals existence depended on advertisements of rental offices, which indirectly decided about the level and content of articles and reviews.]

"Ekran" came back to the press market in Warsaw from January to March 1935. Daniel Libicki was its chief editor and publisher, while the last, third number was published by Karol Ford ${ }^{30}$. Reactivated "Ekran" became a popular instead of artistic periodical, directed to the intelligentsia interested in cinematography. The monthly was modeled on American film journals for the public, although maintaining an artistic character in its form ${ }^{31}$."Ekran" cooperation with outstanding writers, film makers, and journalists, contributed to its high literary and professional level, which ensured its high popularity among the cultural elite of the capital. Among "Ekran" contrubutors were: K. Ford, Jerzy Bossak, Stanisław Felix, Wanda Kalinowska, Zofia Meissnerowa, Jerzy Merson, Józef Steiner, Anatol Ungurian or Jerzy Walden. The journal excelled with articles concerning the film art and culture, materials documenting cinema history and modern film life, as well as film critique. It avoided cheap sensations or gosssip. "Ekran" editors particularly negatively regarded indiscriminate film promotion in press reviews, advertisements at cinema walls or street posters. The "Ekran" valued objective opinions published by the journalists, considering that advertisement aiming solely at attracting a viewer should be countered by the journals offering independent critique ${ }^{32}$. A. Ungurian, "Ekran" journalist, in one of his articles wrote about a film review:

\footnotetext{
28 Ibidem, p.72.

29 Ibidem, p. 145

$30 \quad$ M. Hendrykowska, Kronika ..., p. 44.

31 B. Gierszewska, Czasopiśmiennictwo filmowe..., p. 131.

32 Ibidem, pp.130-132.
} 
W dziedzinie prasy filmowej obok reklamy [...], istnieje jeszcze jedna plaga. Mam na myśli recenzje i pseudorecenzje filmowe. [...] Wszystkich recenzentów filmowych naszego miasta stołecznego podzielić można na kilka grup zasadniczych. A więc po pierwsze - na dwie główne kategorie: tych, którzy piszą o filmie to, co o nim myślą i tych, którzy piszą o filmie to, co im każą. Drugą grupę stanowią wszyscy ci pseudorecenzenci, którzy albo znajdują się na usługach kin i biur filmowych, albo pisują w takich pismach, które uzależnione są bezpośrednio od przemysłu filmowego i z tej zależności ciągną zyski ${ }^{33}$.

[There is another plague in film press, besides advertising [...]. I mean film reviews and pseudo-reviews. [...] All film reviewers of our capital city can be divided into several groups. First - two main categories; those who write about a film what they really think and those, who write about a film what they are told to. The latter includes all those pseudo-reviewers, who are either on the services of cinemas and film offices, or write in the journals directly dependent on the film industry, and make profits from this relationship.]

"Kinema" monthly was a valuable and rich in theoretical film thought; the Russian director Rino Lupo and Helena Olszewska were its originators in 1920.

It was a weekly at the beginning, which changed its frequency from no 4 in 1921, as indicated in the subtitle: "A Monthly Cinematographic, Artistic, I1lustrated, and Global Journal". "Kinema" enjoyed popularity among other film periodicals, mostly due to fitting into expectations of a differentiated group of users. Advertisements of lower aesthetic quality were masked with higher-level articles concerning film topics, which enabled maintenance of an artistic profile of the journal. Leo Belmont, Bronisław Hermelin, Kazimierz Lubecki, Jerzy Henryk Skotnicki, Leon Trystan and Helena Olszewska were among its authors ${ }^{34}$.

The film press was directly related to the film industry. The goal of most film journals was a promotion of the Polish cinematography and its development $^{35}$. It is clearly shown by "Film Polski" (The Polish Film) journal, published in 1923, edited by a director, Franciszek Zyndram-Mucha. This ambitious and well-designed periodical dealt with the achievements of cinematography, its heory and new realization possibilities. Articles directly related to the Polish cinematography, the role of film, its achievements and problems were published in this journal. Sadly, the magazine had not gained more support from the readers and was closed after 5 published issues ${ }^{36}$. The number of new film journals pretending to stay on the Polish market longer than those aforementioned increased in the second half of the 20s. Thus, in the year 1927, "Srebrny Ekran" (Silver Screen) biweekly was established in Grudziądz, originated by Włodzimierz Pełka. In its range and level, it was addressed to the

33 A. Ungurian, Krytyka krytyków, "Ekran" 1935, no 2, p. 28.

34 B. Gierszewska, Czasopiśmiennictwo filmowe..., pp. 151-152.

35 M. Halberda, Polska prasa filmowa do 1939 roku, "Kwartalnik Historii Prasy Polskiej" 1989, no 28/4, pp. 31-32.

36 B. Gierszewska, Czasopiśmiennictwo filmowe..., p. 74. 
intelligentsia and audiences interested in film. The magazine had been published only for 5 months and was closed in 1928.

"Ilustrowany Tygodnik Filmowy" (Illustrated Film Weekly) was established in Łódź in the same year, edited by K. Ford. The "Nasz Film" (Our Film) edited by Wiktor Jaczewski started in the same city in 1927. The journal aimed at promotion of domestic cinema theatres and producers, but besides promotion materials, it published also film news, repertoires of Łódź cinemas, and professional articles. Although the journal was interesting for the film industry and cinema viewers, it was published in 3 issues only. The Lódź periodical "Studio" inaugurated in 1928, edited by Henryk Oppenheim, which resumed in 1929, after publisher's bankruptcy, as "Ilustrowane Studio" (Illustrated Studio), official organ of Zrzeszenie Teatrów Świetlnych Województwa Łódzkiego (Association of Light Theatres of the Łódź Voivodeship). Beautifully illustrated journal, with stars pictures, printed on an art paper, entertained cinema audience to purchase. "Studio", due to cooperation with the professionals, film critics, and filmmakers published articles concerning current problems of the Polish cinema, its social function, and role, or discussions on its development trends ${ }^{37}$.

The following titles were published in Kraków: "Ki-Te-Ra" journal in 1928 by the poet Juliusz Witkower, and "Rewia Filmowa" (Film Revue) biweekly, with chief editor Jan Czesław Sikorowicz, director of the Kraków branch of the Nina Niovilla Film School. Therefore its actual goal was the school promotion. There were only a few independent, self-financed film periodicals in the interwar period.

Press development and its market stability in the $2^{\text {nd }}$ People's Republic of Poland were strongly influenced by relations with institutions and people from the film industry, as well as financial support from industry associations, film companies or film rental offices. These relations resulted in greater possibilities of the film industry to influence content in many journals. Editing teams of "Ekran i Scena" and "Kinema" were put in such a situation in the years 1923-1928, as organs of "Kinofilm" company, as well as "Kino dla Wszystkich" (Cinema for All), subject to the film rental offices "Sfinks" and "Ufa", "Wiadomości Branży Kinematograficznej" (Cinematographic News) or "Ekspres Filmowy i Teatralny" (Film and Theatre Express), which were joined to "Klio Film" and "DianaFilm" companies. These were one of the first titles representing professional institutions or organizations. Periodicals relations with the film industry soon became a standard in the Polish publishing market ${ }^{38}$.

The Polish cinematographic avant-garde spoke critically of the level of the Polish cinematography. It referred mostly to poor quality of domestic

\footnotetext{
37 Ibidem, pp. 162-163.

38 Ibidem, p. 45.
} 
production and increasing commercialization in its postulates. Film critics were helpless in the face of increasing commercialization on the one hand, and postulates of the film avant-garde, constantly silenced by the producers and cinema owners on the other. However, they underlined that film is insufficiently used as a tool of social, education and popularisation impact. In consequence young enthusiasts of cinematography begun to organize in Polish cities, those who were rather searching for deeper values and aims than trashy entertainment in cinema. An example can be Stowarzyszenie Propagandy Filmu Artystycznego "Start" (Association of Artistic Film Propaganda) in Warsaw, promoted by Leon Brun, editor of the "Kino" film journal. L. Brun recruited journalists and young students to his magazine, among others: Jerzy Toeplitz, Władysław Brun, J. Bossak, and Leon Bukowiecki, who joined the newly established organization and as part of its activities searched for real values in the cinema ${ }^{39}$.

The first half of the 30s. is not only the time of fight against cinema commercialization, but first of all of popularisation of one of the greatest inventions of world cinematography - a sound film. Film sound production was an innovative technological revolution, but first of all, a cultural change caused by new possibilities of cinematography. However, the situation at the press market changed slightly. "Dźwięc" (The Sound) journal was established, concerning (as the name indicates) an innovation meant to revolutionize cinematography ${ }^{40}$. "Wiadomości Filmowe. Czasopismo Ilustrowane" (Film News. Illustrated Magazine) journal, resumed in 1925 after being suspended, was of great importance for film and propaganda of the new film art. This periodical aimed at the popularisation of film culture in an artistic aspect. Ignacy RotsztadtMiastecki was its first chief editor, followed by Zdzisław Wójtowicz in 1934, and K. Ford in 1936. The journal returned to I. Rotsztadt-Mistecki in the last three years of its activity, until 1939. The time of K. Ford editorship was a specific period for both "Wiadomości" and the Polish film studies. The following authors cooperated and published there in that time: J. Bossak, L. Brun, Stanisław Felix, Anatol Stern, Jerzy Walden, Ignacy Winter, Wanda Paszkowska, from among the film community: Wiktor Brumer, Józef Jerzy Hertz, Danny Kaden, L. Belmont, Fabian Epstein, Tadeusz Kończyc, Zbigniew Pitera, Mieczysław Szczęsny, and many others. The authors criticized the poor level of Polish films and accused producers and filmmakers of lack of artistry in their films ${ }^{41}$.

"Film" resumed its activity on the Polish press market in 1935, after a failure in 1924, and had been published until the outbreak of World

39 B. Gierszewska, "Kino"(1930-1939) - przełom w czasopiśmiennictwie filmowym, "Folia Bibliologica" 1992-1993, no 40-41, p. 76.

40 B. Gierszewska, Czasopiśmiennictwo filmowe..., p. 47.

41 Ibidem, pp. 165-167. 
War II. It gained recognition and faithful readers, due to its high literary level, despite a large number of advertisements. Its chief editor was Józef Reichman. It concerned issues related either to the film industry or to the artistic values of the cinema. Like "Wiadomości Filmowe", "Film" gathered a group of interesting personalities, supporting the editing team: J. Bossak, L. Brun, Eugeniusz Cękalski, K. Ford, Antoni Słonimski, A. Stern, K. Irzykowski, J. Toeplitz, Jerzy Wyszomirski and the others. Their publications ensured "Film" high position among professional film journals. Their speculations on aesthetical development of film were of literary and artistic character, which was unprecedented in most of the journals focused on the film industry requirements. "Film" profile differed from other titles published before World War II. It was addressed to the professionals, cinematography enthusiasts, expecting discussions concerning cinematography. The authors voiced some criticism of the domestic film industry ${ }^{42}$. "Świat Filmu" (Film World) was close to the aforementioned, published since 1934 and edited by Stefan Kruczkowski. It aimed at the advancement of film culture and artistry. Both the editor and authors stood for socially engaged cinema, which was to disseminate culture in the society. People working for other magazines published also in this title, i.e. K. Ford, Leopold Gleisner, Józef Jerzy Hertz, Wanda Kalinowska (interested in the cinema in a social context), Stanisław Ostrzycki, Władysław Zawistowski, Maria Jehanne Wielopolska, and others. Their constructive criticism in "Świat Filmu" was valuable for the contemporary state of the Polish cinematography. First of all, they regretted the partiality of film critics, who were apt to sign commercial agreements with the editors, cinemas or film rental offices. Polish theoreticians and film experts were aware that there were only a few independents reviewers concerned about the level of film art. They mostly blamed film journals for that, as the latter were not interested in objective reviews. They pointed out that actually the reviews lead readers and enabled them to focus on different aspects of artistic, propaganda, social or education film ${ }^{43}$. M.J. Wielopolska wrote about film critique in the $3^{\text {rd }}$ issue of "Świat Filmu":

Recenzja filmowa jest spychana między ogłoszenia o wodzie vichy i kremie "Elida". Obojętną kwestią jest, czy pojawi się bezpośrednio po premierze, czy w rocznicę. Bardzo mały zastęp ludzi wierzy, bo każdy podejrzewa, że jest zależną od cichych interesów administracji danego pisma, od ogłoszeń kinowych [...] Toteż milej są widziane krytyki entuzjastyczne, wodą różaną skropione, pełne pochwał i zachwytów. Pisma niższej kategorii nakładają wprost kagańce na buzię swego recenzenta, wymagając aby chwalił obrazy, które "płacą ogłoszenia" i ganił te, które nie płacą, a w najlepszym razie, aby przemilczał. Zaś pisma

\footnotetext{
42 Ibidem, pp. 171-172.

43 Ibidem, pp. 123-124.
} 
poważniejsze spychają recenzje filmowe [...] do działu czwarto- i piątorzędnego, po wszystkich recenzjach teatralnych, rewiowych a nawet cyrkowych ${ }^{44}$.

[Film review is pushed down among ads of Vichy water or "Elida" cream. Does not matter if it appears directly after a premiere or on its anniversary. Very small group of people believe, although each suspects, that a review depends on quiet interests of journal administration, of cinema ads [...] Therefore enthusiastic critiques are much more welcome, sprinkled with rose water, full of praise and admiration. Lower category journals simply muzzle their reviewers, expecting them to praise films which "pay ads", and condemn those, which do not pay or conceal them at best. More serious journals push down film reviews $[\ldots]$ to the fourth and fifth level section, after theatre, revue, or even circus reviews.]

Film theoreticians, historians, critics, and makers were aware that film critique in the 30s was influenced by the entrepreneurs intervening in the film press contents. Therefore, only independent, artistic titles, guided by the social and aesthetic ideas of cinematography, could afford brave opinions about film critique, free of pressure.

"Reporter Filmowy" (Film Reporter) journal was established in 1933, influenced by the movement for valuable cinema of "Start" organisation, edited and published by Wiktor Jaczewski, with the following authors: J. Bossak, Eugeniusz Cękalski, Teodor Braude, Dariusz Migot, J. Teoplitz, K. Ford, L.Brun, Jerzy Fredt, L. Belmont. T. Braude, in his article Film jako forma porozumiewania się (Film as a way of communication), published in this journal, developed fundamental ideas of film critique. He wrote:

Krytyk rozumiejąc sztukę filmową, jako jedną z udoskonalonych form społecznego porozumiewania się, będzie przy ocenie filmu stawiał następujące pytania: czy twórca w ogóle miał coś do powiedzenia, jeśli miał, to czy to było z tych czy innych względów słuszne i czy wybrał odpowiednie środki ekspresji filmowej, ze względu na tę kategorię widzów, do której przemawia. Jeśli krytyka filmowa da dostateczną odpowiedź na te trzy pytania, to całkowicie spełni swoje zadanie. Idealny byłby taki film, który by potrafił doprowadzić do absolutnego porozumienia się między twórcą a widzem ${ }^{45}$.

[A critic, understanding the film art as one of the improved forms of social communication, will ask the following questions while evaluating a film: did the author have anything to say at all? If yes, was it right from these or those reasons, and did he/she selected adequate means of film expression, regarding an audience category that he/she speaks to? If a film critique answers satisfactorily these three questions, it fulfills completely its task. Ideal film would be able to lead to an absolute agreement between a creator and a viewer.]

One journal distinguished particularly from among the group of popular and professional film art periodicals in the interwar period. It was "Kino" illustrated weekly, which gained the biggest fame among film magazines, mostly due

44 M.J. Wielkopolska, O krytyce filmowej, "Świat Filmu” 1935, no 3, p. [6].

45 T. Braude, Film jako forma porozumiewania się, "Reporter Filmowy" 1933, no 1, p. 3. 
to large editions and publishing continuity. "Kino" had been published since March 1930 until September 1939, with L. Brun as chief editor, one of the precursors of film press in Poland, who managed this title continuously until 1935. It is thanks to him that "Kino" reached a high standard of content and editing level, as Brun created the journal far from the influences of Polish commerce. It, first of all, focused on the promotion of Polish cinematography among the Poles. The journal offered cultural entertainment as well as general knowledge on cinematography: its history or development trends. It was read mostly by the youth, due to its interesting style, aesthetical arrangement of columns, jocular language or colourful illustrations, film photos, etc. "Kino" became a favorite journal of the audience, standing out with the value of its materials, as it did not avoid in-depth contents. The articles were published by L. Brun, K. Ford, Józef Steiner, Wanda Kalinowska, J. Teoplitz, Stanisław Ostrzycki, and E. Cękalski. Undoubtedly, the success belongs to L. Brun, who answered the readers' needs with the articles published in "Kino" ${ }^{46}$. The editor's said in the foreword to the first issue: "We come straight from the cinema seats. The thought about publishing this journal emerged at the cinema theatre. $[\ldots]$ We came from the theatre and come back there. We would like to bring the best content, the most colourful and the closest to a cinema feeling" ${ }^{47}$. Except for photos of film stars and scenes, the journal offered also film reviews or short descriptions, as well as interviews with film makers, actors, and directors. The next part included articles concerning film history and theory, columns and more serious film critique. The last part offered entertainment, with funny stories, contests, announcements or questionnaires. When L. Brun left "Kino" editing team, in 1935 his function was taken over by Jan Lubicki, who tried to maintain the weekly position. In 1937 he was replaced by Teofil Syga, a journalist and literary expert. He changed the hitherto profile of the journal, depriving it of more serious, valuable film contents. Following publishers' requirements, he created a popular magazine for a wide audience, orientated to more entertainment content. Despite these changes, "Kino' was perceived as a prime example of the good film journalism by film reviewers and creators of professional press ${ }^{48}$. There were many other periodicals in the inter-war period, except those aforementioned, however, they usually quickly failed at the press market. The other changed chief editors, producers or distributors, to come back to the market with a new publishing policy ${ }^{49}$.

46 W. Jewsiewicki, Przemyst filmowy w Polsce w okresie międzywojennym (1919-1939), Łódź 1951, pp. 34-35.

47 Od redakcji, "Kino" 1930, no 1, p. 2.

48 W. Jewsiewicki, Przemyst filmowy w Polsce..., pp. 35-36.

49 M. Halberda, Historia prasy..., p. 31. 


\section{Conclusions}

Film journals published at the Polish market in the years 1913-1939 were different in regard to form, style, language, and contents. Besides informing or entertainment, i.e. fundamental functions of the press, they were also a source of information about Polish and foreign cinematography. Film journals described in this article can be divided into four groups, regarding their contents or subjects. Referring to Barbara Gierszewska ${ }^{50}$ calculations, in the years 1913-1939 (with a break between 1914-1919 due to World War I) the largest group included popular magazines, then promotion and advertisement journals (focused on ads and profit), professional journals (based mostly on information concerning activities of organizations and professionals), and finally a minority of artistic journals.

Tab. 1. Content categorization of journals from the years 1913-1939

\begin{tabular}{|c|c|c|c|}
\hline Artistic journals & Popular magazines & Professional journals & $\begin{array}{l}\text { Promotion and adver- } \\
\text { tisement journals }\end{array}$ \\
\hline Ekran (1919-1920) & $\begin{array}{c}\text { Kino-Teatr i Sport } \\
\text { (1914) }\end{array}$ & $\begin{array}{c}\text { Ekran i Scena } \\
(1923-1932)\end{array}$ & Scena i Ekran (1913) \\
\hline Film Polski (1923) & $\begin{array}{c}\text { Srebrny Ekran } \\
(1927-1928)\end{array}$ & Kinema (1925-1926) & $\begin{array}{l}\text { Teatr i Kino } \\
(1921-1924)\end{array}$ \\
\hline Kino-Film (1927) & Ki-Te-Ra (1928) & $\begin{array}{c}\text { Ekspres Filmowy i Te- } \\
\text { atralny }(1925-1928)\end{array}$ & $\begin{array}{c}\text { Rewia Filmowa } \\
(1928-1929)\end{array}$ \\
\hline Film (1928) & Kino (1930-1939) & Nasz film (1927-1928) & Słońce (1928-1929) \\
\hline $\begin{array}{c}\text { Reporter Filmowy } \\
\quad(1933-1935)\end{array}$ & $\begin{array}{l}\text { Przegląd Filmowy } \\
\text { (1931) }\end{array}$ & $\begin{array}{c}\text { Kino dla Wszystkich } \\
\text { (1928-1934) }\end{array}$ & Scena-Film (1928) \\
\hline $\begin{array}{l}\text { Awangarda } \\
(1933-1934)\end{array}$ & $\begin{array}{c}\text { Przegląd Filmowy, } \\
\text { Teatralny i Radiowy } \\
(1931-1939)\end{array}$ & $\begin{array}{c}\text { Wiadomości Filmowe } \\
\text { (1925) (1933-1939) }\end{array}$ & $\begin{array}{c}\text { Nowości Filmowe } \\
\text { (1931) }\end{array}$ \\
\hline \multirow[t]{4}{*}{ f.a. (1937) } & $\begin{array}{l}\text { Świat Filmu (1934- } \\
\text { 1935) }\end{array}$ & $\begin{array}{c}\text { Wiadomości Branży } \\
\text { Kinematograficznej } \\
(1930) \\
\end{array}$ & $\begin{array}{l}\text { Express Filmowy } \\
(1933-1939)\end{array}$ \\
\hline & Ekran (1935) & Film (1935-1939) & $\begin{array}{c}\text { Nowiny Filmowe } \\
\text { (1936-1938) }\end{array}$ \\
\hline & $\begin{array}{l}\text { Kurier Filmowy } \\
(1936-1939)\end{array}$ & $\begin{array}{l}\text { Prawda o Filmie } \\
\quad(1937-1939)\end{array}$ & Kino (1930-1939) \\
\hline & X Muza (1937-1939) & Aktualności (1939) & \\
\hline
\end{tabular}

50 B. Gierszewska, Czasopiśmiennictwo filmowe..., p. 63. 
There were more film press titles in the years 1913-1939, although most of them did not stay on the market, and declared bankruptcy within a year. Still unstable, not-unified film press, divided among different publishers, sponsors or readers' profiles, had to postpone its ambitions and plans. The development of film journals of the inter-war period was broken by September 1939 events. Most of them did not renew after the war.

Translated by Matgorzata Kisilowska

\section{References}

Belmont L., Hołd kinematografowi, "Wolne Słowo” 1909, no 44-45, pp. 14-16.

Bocheńska J., Polska myśl filmowa do roku 1939, Warszawa 1974.

Braude T., Film jako forma porozumiewania się, "Reporter Filmowy" 1933, no 1, p. 3.

Bystroń J., Socjologia kina, "Ekran” 1919, no 11, pp. 1-3.

Chrzanowski I., W obronie teatru, "Scena i Sztuka" 1909, supplement no 1 to no 37, p. 3.

Dębicki I., Czy kinematograf profanuje dzieło sztuki?, "Tygodnik Ilustrowany” 1911, no 51, p. 1025.

Gierszewska B., “Kino”(1930-1939) - przetom w czasopiśmiennictwie filmowym, "Folia Bibliologica” 1992-1993, no 40-41, pp. 75-85.

Gierszewska B., Czasopiśmiennictwo filmowe w Polsce do 1939 roku, Kielce 1995.

Gierszewska B., Mniszkówna ... i co dalej w polskim kinie?, Kielce 2001.

Habielski R., Ewolucja Prawa Prasowego w Drugiej Rzeczypospolitej. Zakres i recepcja, “Studia Medioznawcze” 2013, no 4 (55), pp. 79-92.

Halberda M., Polska prasa filmowa do 1929 roku, "Kwartalnik Historii Prasy Polskiej" 1989, no 28-4, pp. 23-32.

Hendrykowska M., Kronika kinematografii polskiej 1895-1997, Poznań 1999.

Irzykowski K., Śmierć kinematografu, "Świat” 1913, no 21, pp. 1-3.

Jewsiewicki W., Polska kinematografia w okresie filmu niemego, Łódź 1966.

Jewsiewicki W., Przemysł filmowy w Polsce w okresie międzywojennym (1919-1939), Łódź 1951.

Łojek J., Myśliński J., Władyka W., Dzieje prasy polskiej, Warszawa 1988.

Sobczak J., Dzieje prawa prasowego na ziemiach polskich, Poznań 2009.

Ungurian A., Krytyka krytyków, "Ekran” 1935, no 2, p. 28.

Wielkopolska M.J., O krytyce filmowej, "Świat Filmu” 1935, no 3, p. [6].

Zagórski A., Przyszłość kinematografu, "Scena i Ekran” 1913, no 1, pp. 9-12. 